\title{
Fields and Effects of Corporate Citizenship Participating in Public Welfare
}

\author{
Xueying Tian \\ School of Business \\ Suzhou University of Science and Technology \\ Suzhou, P.R.China \\ e-mail: lucy.txy@163.com
}

\begin{abstract}
With more expectations from all kinds of stakeholders, corporations play an important role in society development. As one of corporate social responsibilities, public welfare which corporations take part in has become more and more popular in the world. Thus, the notion of the corporate citizenship is a significant transition in corporate consciousness as organizations look beyond their own definition and experience to see the broader issues. The author proposes the new understanding of the corporate citizenship. And then the author recognizes six major fields of corporate citizenship participating in public welfare, including disaster relief, poverty reduction, education support, environmental protection, community service and customer/employee satisfaction. After that, effects can be provided from corporation by participating in public welfare, that is, public welfare is not only an important productivity but also can establish the corporate citizenship image. Future research on corporate citizenship would be strengthened in the relationship between competitive advantages and public welfare.
\end{abstract}

Keywords-corporate citizenship; corporate social responsibility; public welfare; fields; effects

\section{INTRODUCTION}

Corporate social responsibility (CSR) has become more and more acute because of numerous problems in product safety, environmental protection, and labor relations, which it is thought are due to the corporations' utter disregard for corporate social responsibility. Under these circumstances the concept of "corporate citizenship" (CC) is put forward and beginning to develop. As a corporate citizenship, enterprise should share some responsibilities to meet all stakeholders' needs in many areas. What's more, enterprises pay more attention to the effects of public welfare, enterprises and entrepreneurs hope that their activities can achieve the desired objectives. With the development of corporate citizenship idea and gradual internationalization, it can be foreseen that all enterprises will participate in public welfare which may be integrated into the strategy of corporation.

The concept of "corporate citizenship" is introduced and a more precise understanding is shown. Then, the author selects six major fields of public welfare which "corporate citizenship" should participate in. After that, effects from two aspects can be analyzed. Finally, the paper makes suggestions on corporations in China to improve competitive advantages by taking part in public welfare.

\section{A NEW UNDERSTANDING OF CORPORATE CITIZENSHIP}

Corporate citizenship (CC) has emerged as a prominent term in the management literature dealing with the social role of business. According to Carroll [1], CC is an extension of a lineage of work in the management literature that conceptualizes the role of business in society. This lineage has, the most notably, been dominated by the notion of corporate social responsibility (CSR). Carroll's [2] widely cited CSR model conceptualizes four types of responsibilities for the corporation: (1) the economic responsibility to be profitable; (2) the legal responsibility to abide by the laws of society; (3) the ethical responsibility to do what is right, just, and fair; and (4) the philanthropic responsibility to contribute to various kinds of social, educational, or cultural purposes. To some extent, however, these concepts have attained a wider and more enthusiastic acceptance in the academic literature than in corporate thinking and practice [3] [4]. CC, meanwhile, has been introduced into the CSR discourse in the last few years, mainly at the instigation of corporate actors.

It is evident, however, that despite the addition of the $\mathrm{CC}$ term to the debate surrounding the social role of business, its usage has not been consistent nor, the author would suggest, particularly clear. But the definition of $\mathrm{CC}$ is put forward by some authoritative organizations, which offers reference for this study. Boston Institute thinks that $\mathrm{CC}$ is an integrated manner which is made up of corporation value, business operation, and policy. The concept of CC considers that enterprise's success has close relation to social health and welfare, so corporation must take into account of the influence on all stakeholders, such as employee, customer, community, supplier, and environment. "Corporate Citizenship Company" also argues that the concept of CC includes four aspects: (1) corporation is the primary part in society; (2) corporation is one of the citizens; (3) corporation has the rights and duties; (4) it is responsible for social development. Clearly, the $\mathrm{CC}$ is fairly more different than that is defined before [5]. The fact that corporation copes with social problems and integrates into society is included, and then it is a guideline which checks corporation's behavior. At the same time, the concept reflects the relationship among 
corporation, society and nation, which needs to be reconstructed.

Good corporate citizenship indicates that it is a new idea and business culture, which results in combination intrinsic enterprise benefit with extrinsic social demand. It proves that social welfare performance of the corporation can help to encourage employees to work hard, improve corporate image, increase enterprise profit, and attract more investors [6]. The president of "Corporate Citizenship Company" in Britain, David Rogan says that as an important part of citizenship, corporation has the right and responsibility to devote to social development. A successful enterprise cannot only make higher profit but also more contributions to the society. Table 1 shows the concept difference between CSR and CC.

TABLE I. THE CONCEPT OF CSR AND CC

\begin{tabular}{|c|l|l|}
\hline \multirow{2}{*}{ Concept } & \multicolumn{2}{|c|}{ Items } \\
\cline { 2 - 3 } CSR & $\begin{array}{l}\text { Object } \\
\text { all }\end{array}$ & \multicolumn{1}{c|}{ Type and key point } \\
\hline stakeholders & $\begin{array}{l}\text { the economic responsibility; } \\
\text { the legal responsibility; } \\
\text { the ethical responsibility; } \\
\text { the philanthropic responsibility }\end{array}$ \\
\hline CC & $\begin{array}{l}\text { all } \\
\text { stakeholders }\end{array}$ & $\begin{array}{l}\text { corporation is the primary part in society; } \\
\text { corporation is one of the citizens; } \\
\text { corporation has the rights and duties; } \\
\text { it is responsible for social development }\end{array}$ \\
\hline
\end{tabular}

\section{FIELDS OF CORPORATE CITIZENSHIP PARTICIPATING IN PUBLIC WELFARE}

For some systematic approach to studies on CSR, therefore, the author selects six major fields of corporate citizenship sharing corporate social responsibility (see figure 1) based on the standards used in the preceding research results and related data.

\section{A. Disaster Relief}

Many corporations make donations, either monetary or in kind, when disasters like epidemics, earthquakes and floods strike nation. Most donations are processed through non-profit organizations (NPOs) and government organizations, such as China Charity Foundation, Red Cross or provincial governments and hospitals located in disaster-stricken areas in China.

\section{B. Poverty Reduction}

Corporations also participate in eliminating poverty by making donations and running education programs. In China, multinational corporations have increasingly been aiming at permanent escape instead of temporary relief from poverty. For this reason, a significant part of poverty aids is practiced in order to improve the level of education in economically underdeveloped areas so that its residents will be able to equip themselves with a better means of living.

\section{Education Support}

Education support is the corporations' top priority in China. The total amount of donation by the top-25 global companies in China amounted to 169.95 million yuan (US\$21.3 million) in 2005 and the amount donated to educational causes accounted for $28 \%$ of it with 46,790,000 yuan [7]. Most of the donation made by the corporations are centered on three areas-the 'Project Hope (a program to support youngsters in poverty-stricken areas),' partnership with domestic universities, and scholarship.

\section{Environmental Protection}

CSR in this field has been carried on in the form of energy conservation and pollution reduction, while often involving the introduction of environment-friendly plants and equipment. Possible effects on the surrounding environment have emerged as an important point of consideration when selecting plant's location. Meanwhile, conservation efforts by companies also extend to develop new products and technologies that conform to environment friendliness. For example, France-based retail giant Carrefour gained publicity by being the first to use environment-friendly shopping bags in China.

\section{E. Community Service}

Community services by corporations involve providing necessary supports to improve local living conditions. At the same time, some corporations aspire to enhance their corporate image and contribute to the local community by providing training in subjects related to their business areas.

\section{F. Customer/Employee Satisfaction}

By extension, raising the level of customer satisfaction and employee welfare is another way for companies to take part in CSR. The automaker provides a pedestrian safety service within its company compound and employee residential areas to ensure the safety of employees' children. GE ran a campaign named 'Future Star' to employees' children, which rewarded winners with scholarships.

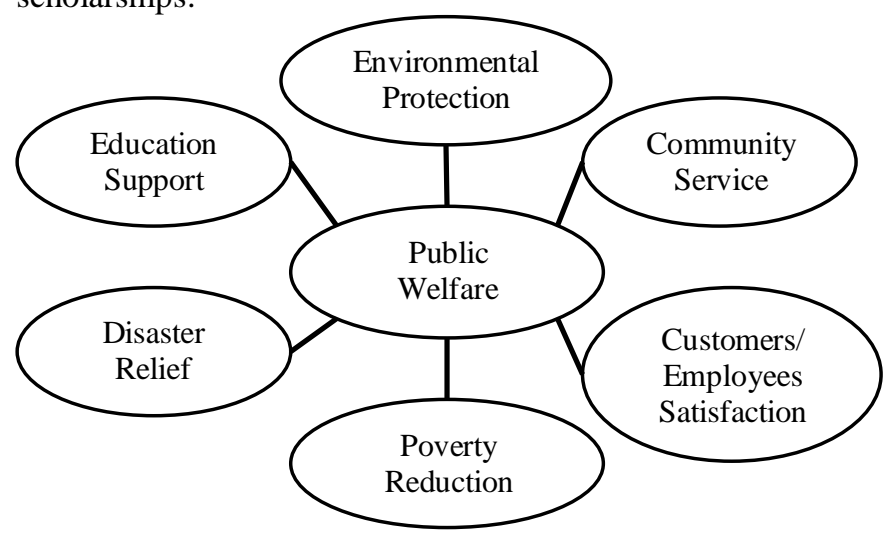

Figure 1. Fields of corporate citizenship participating in public welfare

\section{EFFECTS OF CORPORATE CITIZENSHIP PARTICIPATING IN PUBLIC WELFARE}

Although doing public welfare cannot produce profit directly, it has a remarkable influence on potentially promoting the development of enterprises. Since joining the World Trade Organization (WTO), Chinese economic society is merging with the global integration greatly. In the process of learning from transnational enterprises, the enterprises in China focus more on business administration and market management to improve the for-profit competition quality of enterprises. While they rarely concentrate on and even neglect the strategic intentions of transnational enterprises for giving back to the society to 
construct a favorable enterprise ecology. As for most of the transnational enterprises, to participate in public welfare to act as responsible corporate citizens is carried out as the top priority of their enterprise development strategy, which helps transnational enterprises establish good social images, and it also brings the enterprises more market shares indirectly, which is called "non-profit" competition. The internationally renowned multinational corporations have set up special departments for public affairs in succession. Besides, the public welfare projects in different regions and markets are managed by enterprise senior team directly. Many companies also specially customize public welfare projects for Chinese market.

Facing the more fierce and direct competition, Chinese enterprises have to enhance their competitiveness roundly, including to improve the product quality, to increase investment in science and technology, to promote industry upgrading, etc. Moreover, they have to implement brand strategy to build their own brands. An enterprise with long-term development prospects ought to possess longterm profitability which is based on good enterprise image and continuously cognitive competence of the public. To consciously undertake social responsibilities and participate in public welfare, it plays an important role in obtaining social affinity and public cognition. This is conducive to set up a good enterprise image to expand the space for sustainable development of enterprises. Meanwhile, it can also increase the reputation and enterprise brand of enterprise brand to improve the market shares of enterprises or their products.

\section{A. Being an Important Productivity}

Taking social responsibilities can promote the values and competitiveness of enterprises. To participate in public welfare activities is able to show the public the value orientation of enterprises; meanwhile, it also assumes their social responsibilities and obligations. In turn, all responsible enterprises are striving hard to constantly perfect their value conceptions and spread their values for pursuing a favorable humanity environment to the public so as to promote the progress of the society. This kind of moral orientation conforming to the social main stream can increase enterprises' reputation and improve the internal cohesion to motivate their employees so as to promote the growth of enterprises themselves [8]. Among the more diversified architectures of social values, a good reputation is able to largely support the commitments made in various enterprise's business activities, such as marketing, recruitment, advertising communication, the cooperation with all parties. In this way, the sense of identity and trust from the internal employees and external partners can be increased to enhance the transaction success rate from all aspects and reduce the direct transaction cost. Thereby, public welfare activities can reflect the core value of an enterprise and its cultural essence to the maximum extent. It is also proved by facts that as the products are more homogeneous, to take part in public welfare can satisfy the pursuit of enterprises for uniquely competitive strategy, and it also plays an important role in improving the competitiveness of enterprises.

Public welfare is considered as an influential medium of corporate public relations. To enter a market suggests that the enterprise must be involved into the public relations between the local government, the public and all circles of the society. Many enterprises even propose that "Public relations are the primary productive forces". Undoubtedly, to participate in public welfare is the optimal means to handle public relations, which is certified by multinational enterprises. Basically, to participate in and develop public welfare is regarded as the enterprise culture or development strategy by all mature enterprises, especially multinational enterprises. Regardless of the real purposes of enterprises for being engaged in public welfare activities, to embark on public welfare objectively plays a practical role in integrating the public relations. The international marketing gurus named Philip Kotler pointed out that "to produce the customer orientation with maximum customer satisfaction and long-term consumer welfare is the key to achieve the organizational goals of enterprises". This kind of concept including marketing ecology and sociological reflection requires enterprises to properly handle the relationships between consumer desires, corporate profits and the overall interests of society so as to keep balance and coordination among them.

Thus, in addition to providing high-quality products and services for the public, it is also necessary for enterprises to actively participate in public welfare to undertake the corporate social responsibilities and obligations so as to establish their public images and enhance their competitive powers. It is no exaggeration to say that the good enterprise image is the basis of an enterprise to exist in the society and it is also the most important impetus to promote the sustainable development of an enterprise. The corporate image synthetically reflects the technological and cultural qualities of an enterprise, including scale, products, management, etc. Meanwhile, it also contains its value orientation on assuming the social responsibilities and obligations. Propagating the corporate image by public welfare activities can preferably seek for emotional resonance with the public to increase the cognition of enterprise to all sectors of society, including the government, community, the public, etc [9]. In addition, it is also considered as the optimal public relations mode utilized to establish a good social image of enterprises and enter the target market. Hence, combining public welfare activities with the market practices of enterprises can promote the brand reputation of enterprises while expanding the market shares. Moreover, this method produces the effect that 1 plus 1 is greater than 2 , and it also has a positive and far-reaching effect on the long-term development of enterprises.

\section{B. Establishing the Corporate Citizenship Image}

At present, most of the top 500 enterprises in the world have entered the Chinese market to be a vital part of Chinese economy. What they have done to carry forward their enterprise culture to live up to their values as "corporate citizens" is of great reference significance for Chinese enterprises. In particular, to support and carry out all kinds of public welfare activities in various forms has been one of the major modes of all great corporations to make contributions to the society so far. As a matter of fact, in their concept of corporate citizenship, just like production cost and the cost of raw materials of enterprises, the investment in undertaking social responsibilities has also been an essential expense of business operation. 
The advanced concept of public welfare brought by multinational enterprises promotes the development of Chinese public welfare and also elevates the public spiritedness of Chinese enterprises. More and more Chinese enterprises have been influenced by the strategic thought of multinational enterprises that to be involved in Chinese public welfare is served as a significant part of the strategy for Chinese market [10]. In this case, more Chinese enterprises also begin to seek a new model to establish corporate image and expand the environment needed by the sustainable development of enterprises by participating in public welfare activities. Enterprise group is considered as a crucial part and one of the strong groups in the modern society, while the healthy development of society includes the balanced and coordinated development of every level of society. There is a kind of support and feedback interrelation between the advantaged group and disadvantaged group in society. The favorable interaction between them is an important symbol of the healthy development of society.

Participating in social public welfare is regarded as a long-term competitive strategy to be performed by multinational enterprises. In the circumstances, to be more involved in public welfare so as to improve the corporate citizenship of Chinese enterprises is the competitive strategy to further develop and strengthen Chinese enterprises [11]. To a great extent, it also plays a necessary role in establishing the overall image of Chinese enterprises, and it is considered as a sign of the social progress in China.

\section{CONCLUSIONS}

Friedman had said that the only responsibility of the company was to increase shareholder's benefit, and the other behaviors would decrease shareholder's welfare. But the more facts demonstrate that his conclusion is behind the times, it is not appropriate enough. The social responsibility performance of the company will help to gain better benefit, encourage employees to work hard, retain excellent talents, attract more investors, and enlarge corporation's market. There is no inherent contradiction between improving competitive advantage and making a sincere commitment to society. As it is seen, the more closely company social responsibility is linked to its competitive advantage, the greater contributions will company make to the society.

\section{ACKNOWLEDGMENT}

This work was supported in part by a grant from National Natural Science Foundation of China (Number: 71002017). This work was supported in part by a grant from Philosophical and Social Science Foundation of University in Jiangsu Province (Number: 2014SJB548).

\section{REFERENCES}

[1] Carroll, A. B., "Corporate social responsibility-evolution of a definitional construct," Business \& Society, 1999, 38, pp. 268-295.

[2] Carroll, A. B., "A three-dimensional model of corporate social performance," Academy of Management Review, 1979, 4 pp. 497505.

[3] Beaver, W., "Is the stakeholder model dead?" Business Horizons, 1999, 42(2), pp. 8-12.

[4] Van Luijk, H. J. L., "Business ethics in Europe: A tale of two efforts," In R. Frederick (Ed.), A companion to business ethics: 643-658. Cambridge, MA, \& Oxford: Blackwell, 2001.

[5] Shaw, B., \& Post, F., "A moral basis for corporate philanthropy," Journal of Business Ethics, 1993,12 (10), pp. 745.

[6] Dutton, Jane M., Janet M. Dukerich, and Celia V. Harquail, "Organizational images and member identification," Administrative Science Quarterly, 1994, 39 (2), pp. 239-263.

[7] Samsung Economic Research Institute Beijing Office, "Multinational corporations in China and their corporate social responsibility practices," August 24, 2006[available at http://www.serichina.org/02/reportV.html?g_regseq=20060824000 1\&1_sgbn=\&g_page $=1 \&$ c_menu=0203].

[8] Williamson D, Lynch - Wood G, Ramsay J. "Drivers of environmental behaviour in manufacturing SMEs and the implications for CSR,” Business Ethics, 2006 (67) , pp. 317-330.

[9] Liu Jihan, Wang Jianqiong. "Corporate social responsibility and capital constraints-evidence from the listed companies of China," Management Review, 2012(11), pp.151-157.

[10] Wang Yanting. "On the relationship between corporate citizenship behavior and inclusive growth," Modern Finance and Economics, 2013(2), pp. 94-103.

[11] Shi Sehngxu, Wu Shengyi. "Content, characteristic and implementation mode of corporate citizenship,"Commercial Times, 2014(2),pp.92-93. 